\section{Mitä huipulta näkyy?}

Kantola, Anu \& Kuusela, Hanna (2019). Huipputuloiset. Suomen rikkain promille. Vastapaino. 360 sivua.

HUIPPUTULOISET-teos sai alkusyksystä aikaan poikkeuksellisen julkisen keskustelun. Vauraiden ajattelu kiinnostaa toki. Yllättävää oli se, että keskusteluun nousivat myös metodologiset kysymykset laadullisen ja määrällisen tutkimuksen eroista. Niin maallikot kuin asiantuntijatkin arvioivat tutkimuksen luotettavuutta. Jälkipyykissä nostettiin esiin vielä sukupuoli: kriittisten äänten mukaan naisten tekemä tutkimus katsottiin kelvolliseksi vasta sitten, kun mies niin sanoi.

Teos on muhkea monella tapaa, sivumäärältäänkin. Lukuisat taulukot ja liitteet kertovat tutkimusryhmän pikkutarkasta työstä ja pitkästä tutkimusprosessista. Kirjan aineisto on laaja: 90 haastattelua ja suuri määrä tausta-aineistoa, kuten tilastoja, lehtijuttuja ja verotietoja.

Kirja avaa näkymiä huipputuloisten arkeen ja piirtää esiin kuvan verkottuneesta eliitistä, jossa kaikki tuntevat toisensa: poliittiselle päättäjälle löytyy kyllä kännykkänumero. Suuria paljastuksia ei silti ole tarjolla. Eikä tarvitsekaan, sillä se ei ole teoksen tehtävä. Tarkoitus on - laadullisen tutkimuksen keinoin - luoda kuvausta vauraiden suomalaisten mielenmaisemista.

\section{PROMILLEN JOUKKO JA} VAURAUDEN KESKITTYMINEN

Teos etenee napakasti. Alusta alkaen lukijaa viedään numeroiden, tilastojen, eurojen ja monien muiden vaurauden mittaamista koskevien asioiden äärelle. Ensin selvitetään, ketä ja mitä rikkain promille tarkoittaa: heitä on 4745 , useimmat keski-ikäisiä tai sitä vanhempia, suomalaistaustaisia miehiä.

Vuonna 2016 suurituloisimpaan promilleen kuuluvat tienasivat keskimäärin 684000 euroa, kun suomalaisen keskivertovuositulot ovat 31000 euroa. Muista tulonsaajista promille poikkeaa sitenkin, että useimmat heistä elävät vailla palkkatuloja. Vuokra-, korko-, osinko- ja muut pääomatulot ovat heille tärkein tulolähde.

Vauraus näyttää keskittyvän yhä tiukemmin pienelle joukolle, ja tulohuippu on kivunnut omille askelmilleen. Rikkaiden joukossa tulot lähtivät nousuun 1990-luvun lopulla. Ero muihin tuloryhmiin kasvoi; vuosina 1990-2007 ylimmän prosentin tulot liki kolminkertaistuivat.

Tulojen määrä, joka nostaa rikkaan rikkaimpien joukkoon, on kohonnut. Vuonna 1995 promillen eliittiin pääsi 180000 euron vuosituloilla, vuonna 2014 vaadittiin 340000 euroa. Promillen suurituloisin siivu, viiden prosentin ryhmä, tienasi vuodessa noin 1,8 miljoonaa euroa. Heitä oli vuonna 2016 noin 240 henkilöä.

\section{PERIJÄT, JOHTAJAT JA YRITTÄJÄT}

Kirjassa on kaksi osaa: ensimmäisessä tarkastellaan promillen

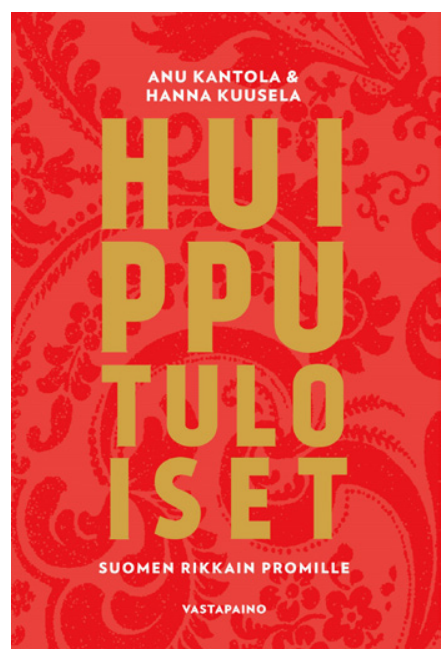

identiteettejä ja kulttuureja, toisessa yhteiskuntaa. Jäsennys on selkeä ja lukijaystävällinen. Selkeyttä tuo myös se, että läpi teoksen puhutaan kolmesta eri ryhmästä, joihin noin 4000 suurituloisinta jakautuvat: perijöitä on 800 , johtajia 1500 ja yrittäjiä 650 henkilöä. Haastatellut edustavat ryhmiä tasaisesti, jokaisesta on mukana noin 30 henkilöä.

Perijöiden ryhmä on kiinnostavin. Ensinnäkin he ovat promillen suurituloisimpia ja toiseksi joukossa vilahtelee tuttuja sukunimiä. Tekijät kuitenkin painottavat, että perijöiden joukko on kirjava: ammatit vaihtelevat hallitusten puheenjohtajista ja toimitusjohtajista taiteilijoihin; sukuvauraus voi olla 1800-luvun lopulta tai vasta parin sukupolven takaa.

Yrittäjät tienaavat liki yhtä hyvin kuin perijät. Heidän omaisuutensa on voinut syntyä hetkessä etenkin exitin kautta eli myymällä oma yritys. Ammattijohtajat edustavat puolestaan palkansaajia, ja heidän käsissään on paljon 


\section{LAADULLISEN TUTKIMUKSEN KEINOIN KUVATAAN}

\section{VAURAIDEN SUOMALAISTEN MIELENMAISEMIA.}

taloudellista ja yhteiskunnallista päätäntävaltaa.

\section{PATRUUNAN TEHTAASTA HOLDING-YRITYKSEEN}

Kaltaiselleni taloushistoriaa huonosti tuntevalle lukijalle perijöitä esittelevä luku oli silmiä avaava. Kirjoittajat käyvät tiiviisti läpi suuret muutokset: feodalismin ja sääty-yhteiskunnan purkautumisen 1700-luvun lopulla, 1800-luvun perhekapitalismin ja taloudellisten dynastioiden synnyn, Suomen teollistumisen ja aateliin kuuluneiden siirtymisen liike-elämään.

Moni tutuksi tullut vauras suku aloitti yritystoiminnan juuri 1800-1900-lukujen taitteessa: Hartwall, Paulig, Herlin, Fazer, Ahlström, Serlachius. Useat yritykset ja niiden perustajat kuitenkin painuivat unholaan yritystoiminnan hiipuessa. Vielä nykyäänkin, haastatteluissa, perijät painottavat vaurauden haurautta.

"Sun pitäisi saada ne kasvamaan jollain tavalla, ja sen jälkeen antaa niitä eteenpäin" omille jälkeläisille, eräs perijä tiivistää. Omaisuus on heidän käsissään vain väliaikaisesti, lainana. Perijät painottavat, kuinka tärkeää on tehdä töitä niin sukuyrityksen eteen kuin palvella Suomea ja kannatella kansakuntaa, kuten tuottaa työpaikkoja.
Kirjoittajat huomauttavat piikikkäästi, että patruuna-asenne kuitenkin katoaa, kun puhe kääntyy kilpailukykyyn ja tuotto-odotuksiin. Ulkomaille siirtymistä ja sijoittamista pidetään tällöin perusteltuna ja vastuullisena yrityksen hoitamisena. Moni yritys on muuttunut patruunoiden ajoista aivan toiseksi: esimerkiksi Hartwallin suvun juomatehtaasta on tullut sijoitusyhtiö.

Hämmästyin, kuinka tuore ajatus omistajien vaurastuttaminen on. Suomalaiset perheyritykset olivat pitkään kitsaita osingonmaksajia. Nykyisiin rahavirtoihin ja omistamiseen täytyy oppia, ja perijät koulutetaan tehtäviinsä. Family officet ja business academyt auttavat eritoten heitä, jotka eivät hakeudu Hankeniin. Ällistystä herätti myös se, että eräs isä oli perustanut lastensa kanssa yhtiön, jonka avulla nuoret voivat harjoitella tulevaa varten. Jo kymmenvuotiaille voidaan siirtää omaisuutta, miljooniakin, jotta he oppivat taloustaitoja ja vastuunkantoa.

\section{"SUOMI ON TASA-ARVOINEN"}

Vasta 1900-luvun alussa syntyi tarve ammattijohtajille, kun teollisuuspatruunat siirtyivät yrityksissä sivummalle. Sotien jälkeen generalistijohtajat vakiinnuttivat asemansa, mitä tukivat johtamiskoulutukset, oppaat ja konsultit.
Odotetusti johtajat puhuvat haastatteluissaan pitkistä päivistä ja kovasta työmoraalista. Ulkoiset merkit ovat vaatimattomia: haastatteluja tehdään tavallisissa neuvotteluhuoneissa, kahvi juodaan pahvimukeista. Johtajat uskovat käsittämättömän vakaasti tasaarvoon, ja kysyttäessä he liki säännönmukaisesti kieltävät suomalaisten jakautumisen eriarvoisiin luokkiin. Jakautuminen on vain hienoista hifistelyä elintavoissa.

Sävy muuttuu sosiaaliturvasta puhuttaessa: puolet kansasta laiskottelee tukien turvin. Suomi on holhousvaltio, jossa itsestä ei tarvitse ottaa vastuuta. Sosiaaliturva passivoi, huono-osaisuus selittyy laiskuudella ja aloitekyvyn puutteella. Julkinen sektori on paisunut valtavaksi - toisin kuin tilastot kertovat.

Passiivisuuden vastakohtana seisovat 2000-luvun sankarit, yrittäjät. He jakavat ihmiset tuottaviin ja tuottamattomiin. Suomen ongelma ovat sosiaalipummit ja työnkaihtajat, ja työntekijät taas ovat liian vaativia.

Kaikkia ryhmiä yhdistää ammattiyhdistysliikkeen ankara kritiikki. Liitot tuottavat "jäykkyyttä”, muun muassa hankaloittavat irtisanomisia. Yhteistä ovat myös synkät arviot demokratian tilasta ja tulevaisuudesta. Vaalit tuottavat moniäänisyyttä, joka on pulma. Tarvittaisiin vahva johtaja, joka selvittäisi erilaisten intressien aiheuttaman sotkun. 
HARVINAISLAATUISTA TIETOA TARJOLLA

Teos on kirjoitettu erinomaisesti. Kieli on sujuvaa ja jouhevaa, enkä huomannut yhtään kirjoitusvirhettä. Lukijan mielenkiinto pysyy yllä: teos etenee ripeästi eikä detaljeihin jäädä roikkumaan. Paikoin jäinkin pohtimaan jonkin yksittäisen sanan merkitystä haastateltavan lausumassa. Tällöin olisin kaivannut kirjoittajien kommentteja ajatuksiini.
Huipputuloiset on ehdottoman suositeltava teos kaikille aikuiskasvatustieteilijöille, jotka ovat kiinnostuneita yhteiskunnallisista hierarkioista, taloudellisesta epätasa-arvosta tai ylipäätään siitä, millainen yhteiskunta tämän päivän Suomi on. Yllättävänkin avoimiksi heittäytyneet haastateltavat kertovat maailmasta, johon muilla ei ole pääsyä. Samalla he osoittavat oman tietämättömyytensä monien "tavallisten suomalaisten” elämästä.
Teoksen avaamaan maisemaan kannattaa kurkistaa, avoimin mielin. Miltä näyttää huipulta katsottuna hyvinvointivaltion tulevaisuus, elämässä pärjääminen tai vaikkapa suhde rahaan ja valtaan? Suosittelen lukemaan teosta etnografin silmin: uteliaana, kyselevänä ja kummastelevana, kriittistä mieltä unohtamatta.

\section{ERJA LAAKKONEN}

$K T, F M$, yliopistonlehtori, Itä-Suomen yliopisto

\section{Tilaa EAEAn uutiskirje,}

nifin saat tietoa eurooppalaisesta aikuiskoulutuksesta kuusi kertaa vuodessa. EAEA on vapaan sivistystyön äänitorvi Euroopassa.

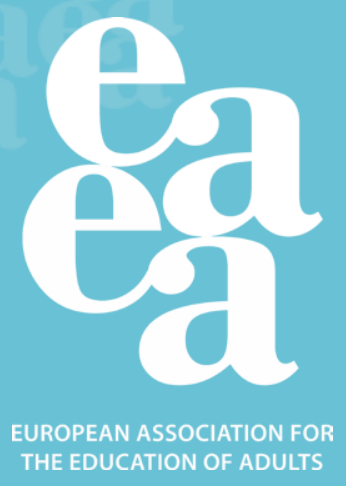

